movements. But its process shows that engaged and even controversial public disputes on violent pasts may enable inclusive and consensual political cultures. Such disputes, however, do contrast the simple lessons of the Holocaust that Marrus rightly criticizes.

Thomas Kühne

Clark University

\title{
Toru Miura, Dynamism in the Urban Society of Damascus: The Salibiyya Quarter from the Twelfth to the Twentieth Centuries (London and Boston: Brill, 2015). 347 pp. Hardback \$159.20.
}

This is the sort of book that is possible to write only after years of continuous research. Toru Miura has been studying Mamluk Damascus and specifically the northern quarter of al-Salihiyya since the 1980s, and therefore brings to Dynamisn in the Urban Society of Damascus: The Salibiyya Quarter from the Twelfth to the Twentieth Centuries the insight and maturity of a life-time of research. ${ }^{1}$

Several themes stand out in Miura's latest work. The long period under discussion allows him to utilize a number of methodologies and various types of primary sources in narrating the historical story of al-Salihiyya. Unlike many studies in pre-modern history published in the last two decades, Miura's familiarity with the subject allows him to develop a narrative that spans an extended time period from the establishment of the quarter in the Ayyubid period until the twentieth century. This is a return to history of the longue durée in a certain microhistorical fashion. Furthermore, the "dynamism" the title refers to is aptly brought to life in the text.

The book is divided into nine chapters in addition to an introduction and conclusion. Chapters one to three follow the establishment of the Salihiyya quarter of Damascus in the Ayyubid period through the Hanbali madrasas that were set there and their awqaf (pious endowments). Miura brings to light the different generations of Hanbali scholars, many of whom were Jerusalemite emigrants to Syria such as the Qudama family, and their role in establishing the quarter. The Abu 'Umar madrasa (college for Islamic higher religious studies) established in 1201-1202 served as a focal point and attracted new migrants to the quarter. Eventually, by the end of Mamluk rule, the quarter hosted thirty madrasas or around $19.7 \%$ of the madrasas of Damascus (63). Miura shows that despite the formative role that Hanbali scholars played in establishing the quarter, eventually the Hanafi scholars became more influential and enjoyed more patronage and support from military governors (69-76). In the third chapter the author analyzes the structure of Salihiyya itself and paints a picture of the sub-quarters or haras within it (which reached thirty to forty). Using the surviving literary 
sources, Miura is able to reach estimates for population figures as well as identify some of the networks among its inhabitants. One of the interesting developments he traces is that relating to the roles of the ulama. Until the end of the thirteenth century the uluma "performed not only the role of religious leader but also took part in military action in critical situations of external danger" (109). However, from the fourteenth to fifteenth centuries, "offices of the waqf institutions, such as the professor of the madrasa, were regarded as being so profitable that the 'ulama' struggled to obtain them, often by giving bribes and by exploiting connections with high government officials" (109). This arguably changed the nature of the relationships between various social groups in the quarter, including the ties between the ulama and other inhabitants. The professionalization of the ulama, which affected some schools more than others, meant that their religious leadership was not what supported popular movements of resistance, whether against invaders like Timur or against government oppression. It was the zu'r (organized and often armed urban male youth groups) ${ }^{2}$ who defended the quarters and represented some form of resistance to oppression, and various groups of ulama extended their influence by joining forces with the zu'r and depending on their military power (110). This insight, if it were to be confirmed by studies of other urban centers in the Arab Middle East, would significantly change our understanding of medieval social history and the political leadership roles long assumed to have been played by the religious scholars.

Chapters four and five focus on general administrative patterns during the late Mamluk period, including the economic challenges the Mamluk regime resorted to and the subsequent "corrupt" practices often referred to in contemporary sources, such as bribery and sale of offices. In those chapters, Salihiyya recedes to the background as the author concentrates on developments in the Mamluk lands at large and, more generally, in Syria and Damascus. The effects of these late Mamluk developments on the quarter are eventually discussed, elucidating how, for example, the ulama of the quarter were forced to open up their madrasas to the other Sunni schools of law beyond the Hanabali in order to attract new awqaf, locate funds, and survive. In chapter five Miura discusses the rise of new urban groups in the late Mamluk period, in particular the zu'r and the ja$m a^{\prime} a$ (household or faction led by an official or judge). Here, the author offers a very interesting theme in connecting the ulama and civil bureaucrats to these developments. Rather than simply see those communities as outlaws and part of the underworld or as outcomes of corrupt bureaucratic behaviour, Miura connects these groups to the changes in administrative practices discussed in the previous chapter. In so doing, he also shows us how the character of the population of the Salihiyya was changing in the fifteenth century. This is one theme through which the historical dynamism of the quarter is elucidated in the narrative.

In chapters six through eight Miura deals with developments in the quarter during the Ottoman period. Here the author follows the story of the awqaf 
that began the text by analyzing waqf surveys and Ottoman central archives as well as some registers of the Shari'a court records that pertain to Salihiyya. These archives, which are familiar to all Ottomanists, allow him to connect some of the dots with the late Mamluk period. Finally, chapter nine draws a picture of decaying religious institutions - many of which had fallen into ruin by the early twentieth century as attested by memoirs and diaries of the period.

In following Damascus and Salihiyya over such a long period of time, the author relies on a variety of primary sources. These include chronologies, biographical dictionaries, awqaf documents, Ottoman archives, Shari'a court records and modern memoires of inhabitants of the city. The book also includes a number of photographs from the author's collection of late twentieth century Salihiyya (although sadly these are not analyzed as historical sources within the text). The sections on the medieval period are stronger than those dealing with Ottoman times, partly as a reflection of the author's own area of specialization and partly due to the dearth of sources on the sixteenth to early eighteenth centuries. In dealing with both medieval and early modern sources, however, Miura analyzes the data quantitatively. There are numerous tables and charts that help bring to light the patterns of waqf establishment as well as sale and lease of (mostly waqf) properties, and estimates of population figures for various constituents. This quantitative analysis of literary and archival sources had become rare in Mamluk studies as more recent works moved back to literary analysis.

In some sense the book traces the rise and decline of al-Salihiyya. And although the rise is easily explained by surviving historical sources, the decline is not so easy to document. In another sense it is a history of the awqaf, as they are the main urban institutions that appear in both Mamluk as well as late Ottoman sources and that allow the author to trace some of the developments of the neighborhood. It is the establishment of awqaf that allowed the madrasas in Salihiyya to flourish, and later the eventual corruption of these awqaf that - the author surmises-led to their ruin and abandonment. Furthermore, the awqaf and their management left enough traces in the surviving historical records to allow the author to follow their rise and decline. Miura's survey of Salihiyya confirms the impression in other sources that the main reason a large percentage of medieval madrasas had fallen into ruin by the nineteenth century was the embezzlement of their awqaf funds, a gradual process that began in the Mamluk period (37 and passim). However, Miura adds to that perspective the argument that both waqf endowment as well as embezzlement should be examined as economic enterprises of the people in changing political and economic situations (38).

Dynamism in the Urban Society of Damascus is also an important contribution to the literature on Arab and Islamic cities. While focusing on a quarter rather than a city as a whole, the story of Salihiyaa is told as part of the larger story of Damascus. One of the important new insights that this book offers is in understanding of the relations between the inhabitants of quarters. Rather than 
stress the homogeneity of the inhabitants of a quarter as an important factor in its solidarity and political action, Miura argues that it was the "plural networks of various social groups such as the Hanbali 'ulama' and the zu'r that integrated the inhabitants into a larger unity as a quarter. The Salihiyya was neither characterized by the Hanbalis, by the military nor by the zu'r, but it was their manifold networks which formed, supported and transformed the Salihiyya quarter in each period," (110).

One of the interesting themes that develop in the book is the discussion of the role of "outlaws" such as the zu'r. The Salihiyya that developed by the end of the Mamluk period was not only a quarter for scholars and military governors, but a vibrant one in which different social groups played roles-including outlaws. Perhaps due to the time frames covered by the surviving sources, Miura is able to draw parallels between the rise of such groups in late Mamluk times and in late Ottoman (i.e. nineteenth century) times. Rather than interpret the roles of such groups as emblematic of general corruption and decline of the ruling order, the author adds the nuance of seeing their roles as ways in which the neighborhoods were able to defend themselves and further their own interests. By the early fifteenth century, the military power of the zu' $r$ was combined with that of the ulama and common people, and used in matters of public concern such as defense against invasion and resistance against injustice (109).

Miura's work is a valuable addition to medieval Islamic histories on cities, and on Damascus and Syria in general. It adds to our understanding of how urban growth happened in practice, and how new neighborhoods and quarters came into being within the larger metropolises and then how they fared over the centuries. Yet, given the attempt at tracing the history of Salihiyya "from the twelfth to the twentieth centuries," readers might expect that the thread of urban development in Damascus and Salihiyya continue to be pulled until the end of the text. Similarly, one expects that the conclusion would provide a more general overview of the long-term history of the city and the placement of Salihiyaa within it. In some sense here the forest was lost for the trees, which are nonetheless dense and vibrant with colour.

Amina Elbendary

American University in Cairo 


\section{NOTES}

${ }^{1}$ Among his publications on the topic see T. Miura, "The Salihiyya Quarter in the Suburbs of Damascus: Its Formation, Structure, and Transformation in the Ayyubid and Mamluk Periods," Bulletin d'études orientales, xlvii (1995), 129-81; and "The Structure of the Quarter and the Role of the Outlaws-The Salihiyya Quarter and the Zu' $r$ in the Mamluk Period," in Urbanism in Islam, The Proceedings of the International Conference on Urbanism in Islam (ICUIT) (Tokyo: The Middle Eastern Culture Center in Japan, 1989), 401-437,

${ }^{2}$ Often considered marginal and part of the disreputable underworld of medieval Syrian cities, the zu'r remain challenging to modern historians trying to understand their social roles. See Th. Bianquis, "Zu'ar", in: Encyclopaedia of Islam, Second Edition, eds. P. Bearman, Th. Bianquis, C.E. Bosworth, E. van Donzel, W.P. Heinrichs. http://dx.doi.org/10.1163/1573-3912_islam_SIM_8185 (Accessed February 7, 2018). 